\title{
Smart home simulation model for synthetic sensor datasets generation
}

Ms.Sc. Darío Weitz / dar.wtz@gmail.com

Denis María / demaria@gmail.com

Franco Lianza / lianza.fl@gmail.com

Nicole Schmidt / nicole.schmidt94@gmail.com

Juan Pablo Nant / jpnant@gmail.com

Departamento Ingeniería en Sistemas de Información / Universidad Tecnológica Nacional, Rosario-Argentina

ABSTRACT World population is ageing due to longer life expectancy worldwide. There is a trend in elderly people to live alone in their habitual residences in spite of health and safety risks. Smart Homes, intelligent environment systems deployed at elderly homes can act as early warning systems trying to forecast the worsening or exacerbation of the resident chronic conditions. Access to sensor datasets is essential for the development of an efficient real smart home. Procurement of such datasets is subject to several restrictions and difficulties. This paper describes the generation of synthetic datasets by means of a simulation model as a suitable alternative previous to the deployment of a real monitoring system. The collection of synthetic datasets will be used during the next project step to train and evaluate activity recognition methods and algorithms.

KEYWORDS Smart home; intelligent environment systems; sensors; simulation; elderly people.

Modelo de simulación de un hogar inteligente para la generación de datos sintéticos de sensores

RESUMEN En el mundo se está verificando un aumento progresivo del porcentaje de personas mayores en la población mundial. Hay una tendencia en los adultos mayores a envejecer en su lugar habitual de residencia, en lugar de utilizar casas de retiro, a pesar de los riesgos y peligros involucrados. Los hogares inteligentes - sistemas de inteligencia ambiental desplegados en las residencias de adultos mayores-, pueden brindar apoyo para compensar el deterioro cognitivo, sensorial o físico de los mismos. La instalación y puesta a punto de hogares inteligentes requiere de conjuntos de datos de sensores que sean representativos de los ambientes que se pretenden monitorear. Existen diversas restricciones y dificultades al momento de evaluar e implementar hogares inteligentes. Se describe un modelo de simulación que permite la obtención de conjuntos de datos sintéticos de sensores para ser utilizados en el desarrollo y entrenamiento de métodos y algoritmos de reconocimiento de actividades, con el fin de identificar automáticamente cambios en las actividades de la vida diaria que sugieran deterioros físicos y/o cognitivos.

PALABRAS CLAVE Hogar inteligente; sistemas de inteligencia ambiental; sensores; simulación; adultos mayores.
Modelo de simulação de uma casa inteligente para a geração de dados sintéticos de sensores

RESUMO Está se verificando no mundo um aumento progressivo da percentagem de idosos na população. Há uma tendência para eles ficarem em seu local de residência habitual, em vez de usar casas de repouso, apesar dos riscos e perigos envolvidos. As casas inteligentes - sistemas de inteligência ambiental implantados nos lares de idosos - podem fornecer suporte para compensar a deterioração cognitiva, sensorial ou física dos mesmos. A instalação e funcionamento de casas inteligentes requerem conjuntos de dados de sensores que sejam representativos dos ambientes que pretendem se monitorar. Existem diversas restrições e dificuldades na hora de avaliar e programar casas inteligentes. É descrito um modelo de simulação que permite a obtenção de conjuntos de dados sintéticos de sensores para ser usados no desenvolvimento e formação de métodos e algoritmos de reconhecimento de atividades, a fim de identificar automaticamente as alterações nas atividades da vida diária que sugiram deterioração física e/ou cognitiva.

PALAVRAS-CHAVE Casa inteligente; sistemas de inteligência ambiental; sensores; simulação; idosos. 


\section{Introduction}

The progressive increase of the older adults proportion over the total population is a phenomenon observed in many countries. The occurrence speed of this phenomenon depends on the living standards and the development degree of each country, due to for the more developed countries this transition has been evident for approximately twenty years. In United States, between 2000 and 2010, the total population grew $9.7 \%$ (from 281.4 million to 308.7 million); however, over the same decade the population over 65 years grew to $15.1 \%$ (Werner, 2011). It is a clear change in the trend until the year 2000, where the growth of the elderly population was slow compared to total growth. In some European Union [EU] countries with a lower level of development - Bulgaria, Estonia, Latvia, Lithuania, Hungary and Romania - life expectancy will increase by more than ten years for men and about eight years for women by 2060 (European Commission, 2014). Thus the more developed EU states will be reached. The age of the population will tend to converge between men and women and to get stabilization country by country, indicating that the transition towards aging societies is unavoidable worldwide.

The population of Argentine Republic will experience significant changes between the years 1990 and 2025. It will increase from 33 million to 47 million, and the mortality rate will decrease in a context of constant improvement of health levels, which will be reflected in an increase of 72 to 78 years in the average life expectancy (Torrado, 2004). These changes, joined to a birth rate reduction, can produce a progressive increase of the older people percentage in the total population.

Aging causes a general deterioration of the individual's abilities, not only the sensory (sight, hearing, etc.) and muscular capacity, it also alters the cognitive or mental capacity. Despite the above, older people have presented a trend towards "on site aging", an opposed lifestyle to the known "retirement homes" or "geriatric residences". In other words, older adults prefer the place where they have lived most of their life, which is familiar and provides them security in spite of their health issues. So, they decide to spend the last years of life autonomously in their own home. Hence, in addition to the environment modification according to their needs, this situation entrusts the satisfaction of an independent and autonomous life.

On-site aging cause risks and hazards, such as falls, accidents with appliances, gas network losses or wrong medication intake. However, even though close relatives of older

\section{Introducción}

El aumento progresivo de la proporción de adultos mayores sobre el total de la población es un fenómeno que se observa en numerosos países. La velocidad con que se presenta dicho fenómeno está en relación con los niveles de vida y con el grado de desarrollo de cada país, para los más desarrollados esta transición se está evidenciando desde hace aproximadamente veinte años, en Estados Unidos, en el período 2000-2010, el total de la población creció 9,7\% (pasó de 281.4 millones a 308.7 millones), sin embargo, durante la misma década la población mayor a 65 años creció al $15,1 \%$ (Werner, 2011). Es un claro cambio en la tendencia que se verificaba hasta el año 2000, donde el crecimiento de la población de edad avanzada era lento con respecto al crecimiento total. En algunos países de la Unión Europea [UE] con menor nivel de desarrollo -Bulgaria, Estonia, Letonia, Lituania, Hungría y Rumania- la esperanza de vida aumentará más de diez años para los hombres y alrededor de ocho para las mujeres hasta 2060 (European Commission, 2014). De esta forma alcanzarán a los Estados más desarrollados de la UE, de modo que la edad de la población tenderá a converger entre hombres y mujeres y a estabilizarse país a país, lo que indica que la transición hacia sociedades envejecidas es inevitable a nivel mundial.

En la República Argentina el panorama demográfico experimentará cambios significativos entre 1990 y 2025, la población crecerá de 33 millones a 47 millones, y la tasa de mortalidad disminuirá en un contexto de mejora constante de los niveles de salud, lo que se verá reflejado en un aumento de 72 a 78 años en la esperanza de vida promedio (Torrado, 2004). Estos cambios, unidos a una disminución de la tasa de natalidad, se traducirán en un aumento progresivo del porcentaje de personas mayores en la población total.

Envejecer trae aparejado un deterioro general de las capacidades del individuo, no solo en lo que respecta a lo sensorial (vista, audición, etc.) y muscular, sino también en cuanto a capacidad cognitiva o mental. A pesar de ello, se está dando la tendencia en los adultos mayores hacia lo que se denomina "envejecimiento en el lugar", estilo de vida en contraposición a los conocidos "hogares de retiro" o "residencias geriátricas", que eran habituales hasta hace algunos años. Aquí el individuo pone en valor el hecho de que el lugar donde ha transitado gran parte de su vida le es familiar y le da seguridad pese a sus dificultades, por lo que prefiere pasar sus últimos años de vida de manera autónoma en su propio hogar. Esta situación, además de permitirle manipular el ambiente según su gusto o necesidad, le confiere la satisfacción de una vida independiente y autónoma.

Envejecer en el lugar trae consigo riesgos y peligros, tales como caídas, accidentes con electrodomésticos, pérdidas en la red de gas o ingesta equivocada de medicamentos. Sin embargo, aun cuando los familiares cercanos de los adultos mayores y sus médicos de confianza conocen los mencionados peligros, y a pesar de que es relativamente común la ocurrencia de accidentes domésticos en los hogares de los 
mayores, la práctica del envejecimiento en el lugar se da cada vez con mayor frecuencia, dando origen a la problemática de brindarles un ambiente seguro para el desarrollo autónomo e independiente de su vida diaria.

Las Actividades de la Vida Diaria [AVD] son parámetros que se utilizan para estimar el nivel de autonomía e independencia de un individuo, son aquellas tareas que los seres humanos desarrollan de manera cotidiana, cuya no realización supone mayor o menor grado de pérdida de funcionalidad (discapacidad), lo que conlleva a una dependencia de terceras personas (Katz, Ford, Moskowitz, Jackson \& Jaffe, 1963). Son numerosos los médicos especializados en geriatría y gerontología que consideran a la identificación de cambios en las AVD como una de las formas para detectar la aparición de enfermedades en sus primeras fases.

Horgas, Wilms y Baltes (1998) clasificaron a las AVD en: básicas, instrumentales y avanzadas. Las primeras se relacionan con el auto-cuidado y la movilidad: dormir, desayunar, cenar, utilizar el baño para higiene, moverse por la propiedad, dar un paseo; Las instrumentales se relacionan con la interacción entre humanos y objetos: mirar televisión, usar una computadora, hablar por teléfono, utilizar electrodomésticos para cocinar o hacer la limpieza general del hábitat; las avanzadas tienen menor énfasis en la vida cotidiana de los adultos mayores y están relacionadas con el trabajo y el tiempo libre.

Los sistemas de inteligencia ambiental, conformados por componentes físicos y entidades de software, permiten hacer un seguimiento automático de un cierto número de AVD. Los componentes físicos incluyen sensores y sistemas en red para obtener registros de localización y actividad: sensores que permiten monitorear la ubicación o actividad de los residentes a lo largo del tiempo, su objetivo es detectar situaciones anómalas que pueden ser el resultado de la falta de actividad o de actividades realizadas por fuera de lo habitual. En el caso de los adultos mayores, algunos ejemplos son: estadías prolongadas en baños o en la cama en horarios no habituales.

Los sistemas de inteligencia ambiental desplegados en las residencias de adultos mayores pueden brindar apoyo para compensar el deterioro cognitivo, sensorial o físico, transformando el hábitat a fin de generar información del residente y compartirla con éste, con sus familiares y con los profesionales que le brindan servicios de salud. Se los denomina Hogares Inteligentes y han sido objeto de profundas investigaciones académicas y privadas, tales como: el proyecto "PlaceLab" del Massachusetts Institute of Technology [MIT] (2015); el proyecto "Gator Tech Smart House" de Florida University (2015); el proyecto Center for Advanced Studies in Adaptive Systems [CASAS] de la Washington State University [WSU] (2015); el Phillips Home Lab de la empresa holandesa Phillips Enterprise Telehealth (2015); y el Samsung SmartThings, perteneciente a la empresa Samsung (2015). Entre las conclusiones arribadas se indica que la instalación y puesta a punto de hogares inteligentes es adults and their physicians are aware of the aforementioned hazards, and despite the common occurrence of domestic accidents in elderly homes, the on-site aging practice is very popular. Hence the importance of providing them a safe environment for the autonomous and independent development of their daily lives.

Everyday Activities [EA] are parameters used to estimate the autonomy and independence level of an individual. They are tasks developed by humans in a day-to-day manner, whose non-implementation implies a greater or lesser degree of functionality loss (disability). Thus, they have to depend on third parties (Katz, Ford, Moskowitz, Jackson \& Jaffe, 1963). There are several physicians specialized in geriatrics and gerontology who consider the identification of changes in EA as one of the ways to detect the appearance of diseases in their early stages.

Horgas, Wilms and Baltes (1998) classified EA as shown below: basic, instrumental and advanced. The basic activities are related to self-care and mobility: sleeping, eating breakfast, using the bathroom for hygiene, moving around the property, taking a walk. The instrumental activities are related to the interaction between humans and objects: watching television, using a computer, talking on the phone, using appliances to cook or doing general cleaning; the advanced activities present less emphasis on the elderly daily life; these latter are related to work and leisure.

Environmental intelligence systems are composed of physical components and software entities. They automatically track a certain number of EA. Physical components include sensors and network systems in order to obtain location and activity records: the sensors that allow a location monitoring or residents activity over time. Its purpose consists of detecting abnormal situations that may be the result of activity lack or activities performed outside the usual. In the elderly case, some examples are shown as prolonged stays in bathrooms or in bed at unusual times.

Environmental intelligence systems deployed in senior residences can provide support to compensate the cognitive, sensory or physical impairment through the habitat modification, in order to generate information for the resident and share it with their relatives and professionals who provide them Health services. They are called Smart Homes [SH], which have undergone to extensive academic and private research, such as the Massachusetts Institute of Technology (MIT) (2015) "PlaceLab" project; The Florida Gator Tech Smart House project (2015); The Washington State University's Center for Advanced Studies in Adaptive Sys- 
tems [CASAS] (2015); The Phillips Home Lab of Phillips Enterprise Telehealth (2015); And the Samsung SmartThings, owned by Samsung (2015). As one of the main conclusions, the installation and setup of Smart Homes is a highly complex process, that the industry lacks an appropriate integration between sensing, data collection, and remote transmission technologies (Brownsell, Blackburn \& Hawley, 2008). Besides, the idea of remote surveillance as intrusive in the privacy of people with functional limitations is criticized. Finally, the high cost involved in transforming a "standard" environment into a "smart" environment is questioned.

In spite of the above, it is essential to advance in the smart homes development, since the worsening or exacerbation of chronic diseases can be predicted with the respective decrease of the amount and duration of the older adults in health care centers. The above can result in improvements in their life quality, costs of public health services reduction and the tranquility of the families involved.

The installation and set up of Smart Homes requires data sets of sensors representative of the environments that have to be monitored. There are public data sets that could be used for the training and evaluation of environmental intelligence systems, such as the aforementioned CASAS project or the data set produced by Van Kasteren (2015). The latter published the records obtained along 28 days. It included motion sensors, filming, accelerometers and RFID readers. Its use in other projects is questioned due to the recruited volunteers did not always belong to the age group of older adults. Filming is considered an excessively intrusive monitoring alternative, the data stored are very specific to the culture of the registration country and scarcely reliable, because the subjects under study tend to behave on a different way when they are observed.

The implementation and evaluation of a real environmental intelligence system describes several constraints and difficulties: the high cost, due to the need to experiment with different technologies and diverse configurations of sensors and architectures for a long time. Otherwise, the need to generate a clinical trial protocol is shown, since experiments are being conducted with humans. Also, the difficulty of recruiting participants, who must accept the installation of an intrusive system in their home without (usually) receiving economic compensation. As well as the need to collect data over a very long period of time, in order to capture those events rep- un proceso de alta complejidad, que la industria carece de una apropiada integración entre las tecnologías de sensado, recopilación de datos y transmisión remota (Brownsell, Blackburn \& Hawley, 2008) y se critica la idea de la vigilancia remota como intrusiva en la intimidad de personas con limitaciones funcionales. Por último, se cuestiona el costo elevado que implica transformar un ambiente "estándar" en un ambiente "inteligente".

Pese a lo anterior, es de fundamental importancia avanzar en el desarrollo de hogares inteligentes, puesto que los mismos permitirán predecir el agravamiento o exacerbación de enfermedades crónicas con la correspondiente disminución en la cantidad y duración de ingresos de los adultos mayores a los centros de salud. Todo ello redundará en mejoras en la calidad de vida de los mismos, en la reducción de costos de los servicios públicos de salud y en la tranquilidad de los familiares de los mayores involucrados.

La instalación y puesta a punto de hogares inteligentes requiere de conjuntos de datos de sensores que sean representativos de los ambientes que se pretende monitorear. Existen conjuntos de datos públicos que podrían ser utilizados para el entrenamiento y evaluación de sistemas de inteligencia ambiental, como el ya citado proyecto CASAS o el conjunto de datos producido por Van Kasteren (2015). Este último publicó los registros obtenidos durante 28 días con sensores de movimiento, filmaciones, acelerómetros y lectores RFID. Su utilización en otros proyectos está cuestionada porque los voluntarios reclutados no siempre pertenecieron a la franja etaria de adultos mayores, las filmaciones se consideran una alternativa de monitoreo excesivamente intrusiva, los datos almacenados son muy específicos de la cultura del país de registro y escasamente confiables porque los sujetos bajo estudio suelen comportarse de manera diferente al sentirse observados.

La implementación y evaluación de un sistema real de inteligencia ambiental muestra varias restricciones y dificultades: el elevado costo, debido a la necesidad de experimentar durante un largo tiempo con diferentes tecnologías y diversas configuraciones de sensores y arquitecturas; la necesidad de conformar un protocolo de ensayo clínico, puesto que se están realizando experimentos con seres humanos; la dificultad para reclutar participantes, quienes deben aceptar la instalación en su hogar de un sistema intrusivo sin (habitualmente) recibir compensación económica a cambio; la necesidad de recolectar datos durante un período muy prolongado de tiempo, para poder capturar aquellos eventos que representen conductas típicas de los residentes y eventuales sucesos anormales; y la dificultad para evaluar escenarios que impliquen riesgos, tales como caídas, pérdidas de gas, humos, para los residentes del hogar inteligente (Cardinaux, Brownsell, Bradley \& Hawley, 2013).

A partir de argumentos similares a los indicados previamente, Synnott, Nugent y Jeffers (2015) sugieren que la solución a tales restricciones y dificultades puede consistir en la generación de conjuntos de datos sintéticos de sen- 
sores mediante la utilización de sistemas de inteligencia ambiental simulados, los mismos facilitan la obtención de enormes conjuntos de datos, permiten experimentar y poner a punto diversas configuraciones tecnológicas, plantear escenarios de riesgos y anormalidades a bajo costo, en un tiempo relativamente breve y sin riesgos o perjuicios a eventuales residentes. La literatura reporta un cierto número de simuladores o modelos de simulación que se emplean para evaluar sistemas de inteligencia ambiental, pero la elevada complejidad del problema no ha permitido obtener aún una solución definitiva (Paré, Jaana \& Sicotte, 2007; Acampora, Cook, Rashidi, \& Vasilakos, 2013).

El objetivo del presente trabajo es describir un modelo de simulación de un sistema de inteligencia ambiental que genera conjuntos de datos sintéticos de sensores que serán utilizados para el desarrollo de algoritmos de reconocimiento de actividades que permitan identificar automáticamente cambios en las AVD que sugieran deterioros físicos y/o cognitivos.

\section{Simulación}

La mayoría de los sistemas del mundo real muestran una complejidad tal, que inhiben su resolución mediante modelos analíticos. Por tal motivo, se utiliza la técnica de simulación como enfoque alternativo para modelizar al sistema bajo estudio y calcular ciertas medidas de rendimiento que permiten ganar comprensión sobre el funcionamiento del mismo. Se define a la simulación como el proceso de construir un modelo matemático o lógico de un sistema o problema de decisión, y experimentar con el modelo para obtener conocimiento del mismo o para asistir en la toma de decisiones (Law \& Kelton, 2000). En el caso particular de hogares inteligentes, la utilización apropiada de la técnica de simulación permite realizar experimentos con el objetivo de evaluar diferentes configuraciones y obtener datos sintéticos de sensores de manera relativamente rápida.

El modelo de simulación descripto en el presente trabajo se desarrolló mediante el lenguaje de programación C\#, utilizando Microsoft Visual Studio 2012 como framework de desarrollo; el modelado de la vista 3D se realizó mediante el software SketchUp Pro 2015, utilizando componentes de la galería 3D Warehouse; el renderizado del modelo se realizó con el software SU Podium V2.5 Plus; las líneas de redes de sensores se dibujaron mediante Visual Basic Power Packs Line and Shape Controls; la librería ZedGraph se empleó para la construcción de gráficos y curvas; y el motor de base de datos para el almacenamiento de datos y resultados fue Microsoft SQL Server 2008.

El algoritmo de simulación se desarrolló según el esquema de modelado de simulación de eventos discretos. Es una clase de modelo de simulación que consta de tres dimensiones: dinámica, discreta y estocástica. La dimensión dinámica involucra el pasaje del tiempo simulado y una representación explícita de la secuencia de actividades que realiza el residente del habitat simulado; la dimensión discreta indica resenting typical residents' behavior and eventual abnormal events. And finally, the difficulty to evaluate scenarios which involve hazards, such as falls, gas losses, and smoke for Smart Home residents (Cardinaux, Brownsell, Bradley \& Hawley, 2013).

Synnott, Nugent, and Jeffers (2015) suggest that these constraints and difficulties solution may be generated through synthetic sensor data sets with simulated environmental intelligence systems. The latter facilitates the obtaining of huge data sets, also they allow to experiment and to set up diverse technological configurations, to plan risks scenarios and abnormalities at low cost, all above in a relatively short time and without risks or prejudices to eventual residents. The literature reports a number of simulators or simulation models that are used to evaluate environmental intelligence systems, however the high complexity of the issue has not enabled a definitive solution yet (Paré, Jaana \& Sicotte, 2007; Acampora, Cook, Rashidi, \& Vasilakos, 2013).

The objective of the current research consists of describing an environmental intelligence system simulation model that generates synthetic data sets of sensors. It will be used for the development of activity recognition algorithms that allow to automatically identify changes in the EA that suggest physical and/or cognitive worsening.

\section{Simulation}

Most of the real world systems such complexity, which inhibits their resolution through analytical models. For this reason, the simulation technique is used as an alternative approach to model the system under study, and to calculate the performance measures that allows an understanding of the system functioning. Simulation is defined as the process of mathematical model construction or a system or a decision problem. It is tested through a model, in order to obtain knowledge or to assist in decision making (Law \& Kelton, 2000). In a particular case of Smart Homes, the suitable use of the simulation technique allows experiments to be performed with the purpose of evaluating different settings and obtaining synthetic sensor data in a faster way.

The simulation model described in the current study was developed using the $\mathrm{C}$ \# programming language, using $\mathrm{Mi}$ crosoft Visual Studio 2012 as a development framework. The modeling of the $3 \mathrm{D}$ vision was created by the software SketchUp pro 2015, using components of the warehouse 3D gallery. Rendering of the model was performed with SU Plus Podium V2.5 software; Sensor network lines are 
drawn using Visual Basic Power Packs Line and Shape Controls; The ZedGraph library was used for graphs and curves construction; and finally, the database engine for storing data and results was Microsoft SQL Server 2008.

The simulation algorithm was developed according to the discrete event simulation modeling scheme. It is a kind of simulation model that consists of three dimensions: dynamic, discrete and stochastic. The dynamic dimension involves the passage of simulated time and an explicit representation of the activities sequence performed by the resident of the simulated habitat. The discrete dimension indicates that the events of interest change at separate points in time. The stochastic dimension allows us to model the unpredictable behavior of human beings in their daily activities. The discrete event simulation technique allows modeling complex systems with a high level of detail and the resulting model remains "transparent" for non-technical users.

Discrete event simulation models can be formulated under three different approaches: event-oriented; process oriented; or as an activities exploration. The activity exploration approach emphasizes a review about all the activities present in the simulation in order to determine which can start or end the next progress of the simulation clock. It is computationally less efficient than the other approaches and therefore it is the least used. However, it is considered the most appropriate for the elderly daily activities simulation, due to it allows to describe activities that occur during fixed intervals of time (day, week, month, etc.). So, the activity is defined with a pair of events: one that initiates and another that completes a transformation operation of the entity state. Activities have finite periods and state changes are seen at the beginning or end of each one.

The algorithm includes an animation scheme which allows a visual representation of the sequence of activities performed by the resident of the simulated habitat. The animation is defined as a graphical display that modifies its structure or other property over time and causes the perception of a continuous improvement (Schnotz \& Lowe, 2008). Animation contributes to the validation process of the simulation model - to ensure that the model is an adequate representation of reality - by allowing relatives and/ or health professionals to visualize activities sequence. In addition, the system includes the possibility of performing the simulation without the animation process, only when the objective is the system test or production runs. que los eventos de interés cambian en puntos separados en el tiempo; la dimensión estocástica permite modelar la conducta relativamente impredecible que tienen los seres humanos en sus actividades diarias. La técnica de simulación de eventos discretos permite modelar sistemas complejos con un elevado nivel de detalle y aún así, el modelo resultante permanece "transparente" para usuarios no técnicos del mismo.

Los modelos de simulación de eventos discretos pueden ser formulados bajo tres diferentes enfoques: orientado a los eventos; orientado a los procesos; o como exploración de actividades. El enfoque exploración de actividades enfatiza una revisión de todas las actividades presentes en la simulación para determinar cuál puede iniciar o finalizar al siguiente avance del reloj de la simulación. Es computacionalmente menos eficiente que los otros enfoques y por ello se lo utiliza menos, pero se considera el más apropiado para la simulación de las actividades diarias de un adulto mayor porque permite describir actividades que ocurren durante intervalos fijos de tiempo (día, semana, mes, etc.). Se define a la actividad con un par de eventos: uno que inicia y otro que completa una operación que transforma el estado de una entidad. Las actividades tienen duraciones finitas y los cambios de estado se observan al comienzo o al final de la misma.

El algoritmo incluye un esquema de animación para permitir una representación visual de la secuencia de actividades que realiza el residente del habitat simulado. Se define a la animación como una visualización gráfica que cambia su estructura u otra propiedad a lo largo del tiempo, y que dispara la percepción de un cambio continuo (Schnotz \& Lowe, 2008). La animación colabora en el proceso de validación del modelo de simulación -asegurar que el modelo sea una adecuada representación de la realidad-al permitir que los familiares y/o los profesionales de la salud involucrados visualicen la secuencia de actividades. Adicionalmente, el sistema incluye la posibilidad de realizar la simulación sin el proceso de animación, cuando el objetivo es la prueba del sistema o la realización de corridas de producción.

\section{SIMULACIÓN DE UN HOGAR INTELIGENTE}

Un hogar inteligente es una residencia a la cual se le incorporan sensores para monitorear el ambiente, y dispositivos para proveer servicios proactivos que mejoran la calidad de vida y seguridad de los residentes. La simulación de hogares inteligentes para la generación de datos sintéticos se puede realizar a través de dos enfoques claramente diferenciados: enfoques basados en modelos o enfoques interactivos (Synnott et al., 2015). El primer enfoque se basa en la especificación de modelos de actividad que describen el orden de los sucesos, la probabilidad de su ocurrencia, el tiempo de duración de la actividad y el rango de valores de los sensores que definen el estado de una entidad. La calidad del conjunto de datos resultante depende básicamente de la calidad del modelo de actividad subyacente en el modelo de 
simulación, el cual a su vez depende de la disponibilidad de información apropiada sobre las actividades que realiza el residente simulado. Por su parte, los enfoques interactivos ponen el énfasis en el modelado de los ambientes virtuales y de los sensores virtuales por sobre el modelado de las actividades, y facilitan la obtención de datos sintéticos relacionados con cambios o modificaciones en los ambientes o en la cantidad, despliegue o ubicación de los sensores.

El modelo de simulación descrito en el presente trabajo utiliza el enfoque basado en modelos y está conformado por tres componentes: el residente del habitat simulado; el ambiente simulado; y la red de sensores y la arquitectura del sistema.

El primer componente muestra que el modelo está restringido a la detección de las AVD de un único residente, no implica una severa restricción debido a que la coexistencia de dos o más personas en una residencia permite una mutua evaluación del estado de salud superior al de cualquier sistema de información.

El ambiente simulado sigue los lineamientos generales de los hogares inteligentes descritos en la introducción y consta de un dormitorio, un living con televisor, un estudio con computadora, una cocina completamente equipada con una mesa y sillas, y un baño.

La red de sensores simulada corresponde a sensores inalámbricos embebidos en el ambiente, se trata de un conjunto de dispositivos autónomos, distribuidos físicamente en la residencia a monitorear, que se comunican mediante algún tipo de tecnología inalámbrica, su topología es flexible y no requieren de un número mínimo para su funcionamiento. Un módulo de gestión de sensores permite la incorporación de diversas marcas, modelos y proveedores de sensores de movimiento, temperatura, humedad, ocupación de cama y/o sillón (Figura 1). También sensores magnéticos de apertura de puertas, de sonido, fotocontrol y detectores de humo, gas natural y monóxido de carbono. Haciendo clic derecho sobre cuadrados azules dibujados en los distintos ambientes de la residencia simulada se pueden agregar o quitar sensores, activarlos o desactivarlos. El sistema permi-

\section{Smart home simulation}

A Smart Home is a residence compound of sensors for environment monitoring, and devices to test proactive services that improve the life quality and the resident's safety. Smart Home simulation for synthetic data generation is generated by clearly differentiated approaches: model-based approaches or interactive approaches (Synnott et al., 2015). The first approach is based on activity models specification which describes events order, the occurrence probability, the activity duration and the senses values range that define the state of an entity. The quality of the data set resulted basically from the quality of the underlying activity model in the simulation model, which depends on the appropriate information availability about the activities performed by the simulated resident. On the other hand, the interactive approaches emphasize the model of the virtual environments and the virtual sensors by the modeling of the activities. Besides, they facilitate the obtaining of synthetic data related to modifications in the environments or in the quantity, deployment or sensors location.

The simulation model described in this paper uses the model-based approach. It is compound by three components: the resident of the simulated habitat; the simulated environment; and the sensor network and system architecture.

The first component shows the model restriction to the EA detection of a single resident. It does not assume a severe restriction since the coexistence of two more people in a residence allows a mutual evaluation of the health status which exceeds any information system.

The simulated environment follows the general guidelines of Smart Homes described in the introduction. They consist of a bedroom, a living room with TV, a study with computer, a fully equipped kitchen with a table and chairs, and a

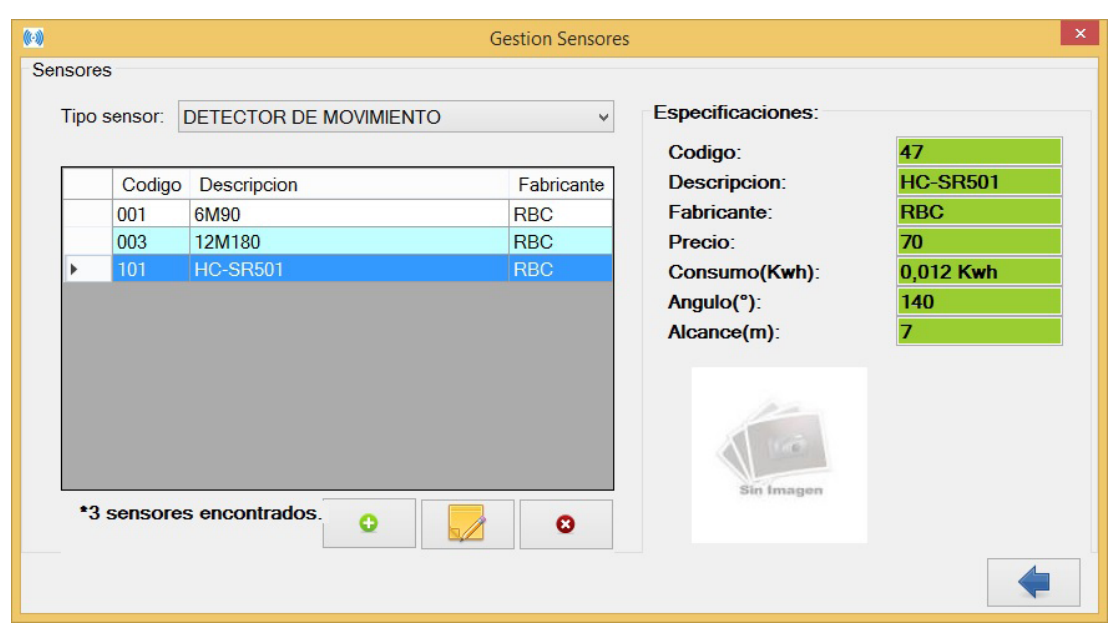

Figure 1. Sensor's management module / Módulo de gestión de sensores bathroom.

The simulated sensor network corresponds to wireless sensors embedded in the environment. It is a set of security devices, physically distributed along the monitoring residence, communicated by some type of wireless technology. It presents a flexible topology and it does not require a minimum number for its operation. A sensor management module allows the incorporation of several brands, models, and suppliers of movement sensors, temperature, humidity, bed occupancy and/or armchair (FIG- 
URE 1). As well as magnetic sensors for opening doors, sound, photo control and smoke detectors, natural gas and carbon monoxide. Right clicking on blue squares is drawn in different environments of the simulated residence. They can add or remove sensors, activate or deactivate them. This system allows to setup the probability of a disaster occurrence (fire, loss of gas, etc.), through the probability distribution between the different rooms of the residence.

The underlying activity model proposes an EA sequence generated from specific probability distributions. They correspond to the start time and the duration of basic and instrumental activities set. Such probability distributions are obtained from empirical data collection, and followed by a consistency analysis and the use of data adjustment software. The simulation proceeds according to a mechanism of four stages: Generation of the sequence of activities; Advance of the simulated time to the occurrence time of the next activity; Activation of the corresponding sensors; and database storage of simulated time, activity and activated sensors. If the occurrence time of one or more activities overlaps with another activity in process, the algorithm places the first in a queue and executes them according to a scheme FIFO [First In First Out]. The sequence of random numbers necessary to generate the random variables of probability distributions is obtained from the generator provided by programming language. The microprocessor clock or a value entered from the keyboard is used as seed. The latter alternative allows the sequence of random numbers to be used throughout the verification step in order to ensure that the simulation model is free of logical errors. te configurar la probabilidad de ocurrencia de un siniestro (incendio, pérdida de gas, etc.), distribuyendo esa probabilidad entre las diferentes habitaciones de la residencia.

El modelo de actividad subyacente propone una secuencia de AVD que se genera a partir de distribuciones de probabilidad específicas que corresponden a la hora de inicio y a la duración de un conjunto de actividades básicas e instrumentales. Tales distribuciones de probabilidad se obtienen a partir de la recolección de datos empíricos, seguido de un análisis de consistencia y la utilización de software de ajuste de datos. La simulación procede según un mecanismo de cuatro etapas: generación de la secuencia de actividades; avance del tiempo simulado al tiempo de ocurrencia de la próxima actividad; activación de los correspondientes sensores; y almacenamiento en base de datos del tiempo simulado, actividad y sensores activados. Si el tiempo de ocurrencia de una o más actividades se solapa con otra actividad en proceso, el algoritmo coloca a las primeras en una cola de espera y procede a ejecutarlas según un esquema FIFO [First In First Out]. La secuencia de números aleatorios imprescindibles para generar las variables aleatorias correspondientes a las distribuciones de probabilidad se obtiene a partir del generador provisto por el lenguaje de programación utilizando como semilla el reloj del microprocesador o un valor ingresado desde teclado. Esta última alternativa permite repetir la secuencia de números aleatorios y se la utiliza durante la etapa de verificación, para asegurar que el modelo de simulación esté libre de errores lógicos.

\section{Resultados y discusión}

El perfil del residente del habitat simulado corresponde a un adulto mayor que vive solo en su residencia habitual, posee algún tipo de enfermedad crónica, pero no se encuentra limitado en sus desplazamientos por el interior o exterior de la propiedad. Los datos para generar la secuencia de ac-

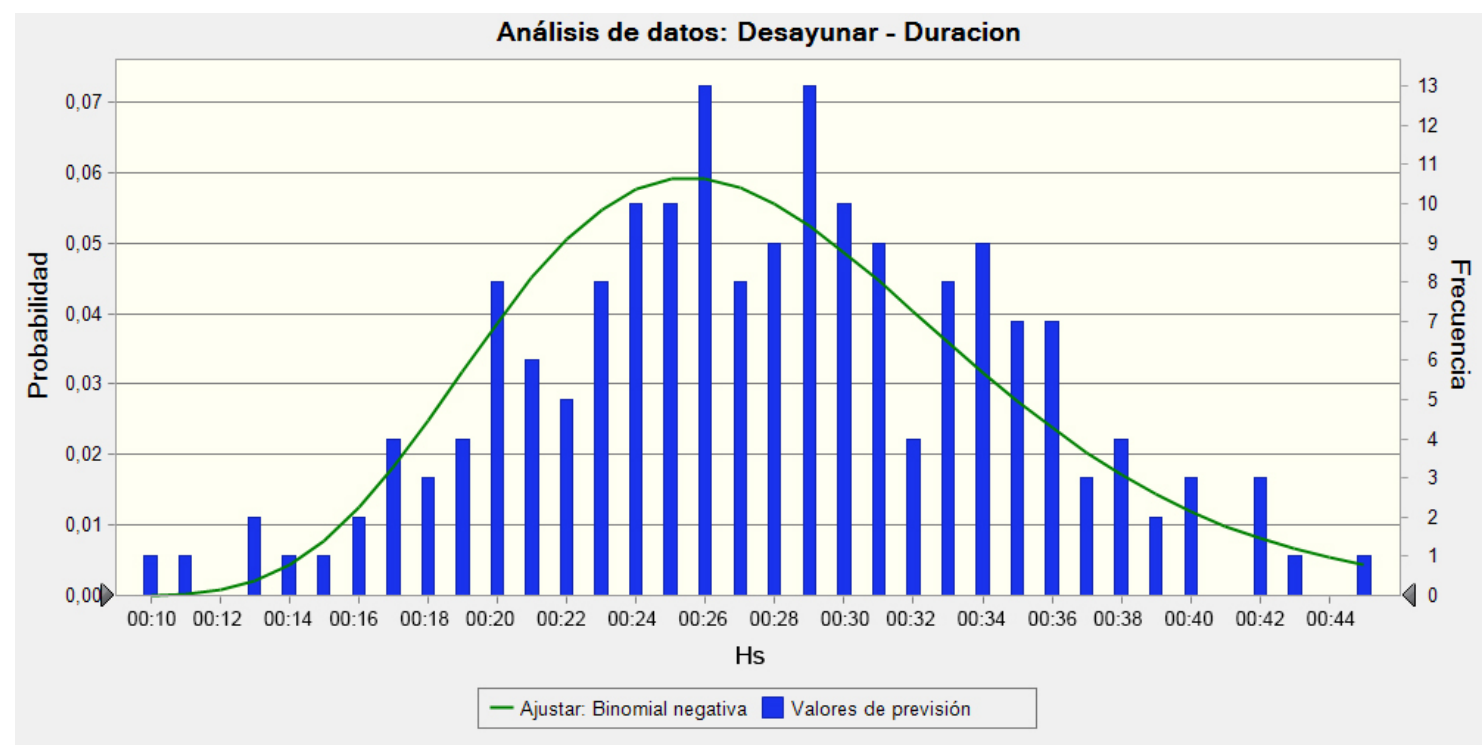

Figure 2. Adjust to activity "breakfast" - duration /Ajuste de la actividad desayunar - duración 
tividades se obtuvieron a partir del llenado de una planilla de actividades diarias realizadas por una mujer de 81 años de edad que vive sola en su domicilio particular. Algunos datos ausentes, por omisión u olvido, fueron completados mediante la función "Datos Aleatorios" del Menú "Calc" del software Minitab. Los datos fueron ingresados a una planilla en MS-Excel y posteriormente procesados mediante el software Crystal Ball (Evans \& Olson, 1998) para obtener las funciones de distribución de probabilidad (con sus correspondientes parámetros) de la hora de inicio y duración de las actividades básicas e instrumentales que mejor ajustaron a los datos recolectados. LA Figura 2 muestra el mejor ajuste determinado por el software Crystal Ball a los datos recolectados para la propiedad "Duración" de la actividad "Desayunar". Para otras actividades registradas en la planilla se obtuvieron las siguientes distribuciones de probabilidad -la información entre paréntesis indica el valor de la prueba Anderson-Darling): dormir: hora de inicio: Weibull $(0,5227)$; desayunar: hora de inicio, beta $(0,1635)$; duración, binomial negativa; almorzar: hora de inicio, logística $(0,3434)$; duración, binomial negativa; merendar: hora de inicio, normal (0,2004), duración, binomial; cenar: hora de inicio, logarítmico normal $(0,1940)$, duración, Poisson.

Las redes de sensores inalámbricos fueron ensayadas mediante su instalación en residencias de familiares de autores del proyecto. Se evaluó el funcionamiento de los sensores, la facilidad de instalación, el consumo de energía y la comunicación mediante el protocolo ZigBee (IEEE 802.15.4). La Figura 3 muestra cómo el uso combinado de sensores de temperatura, humedad y luminosidad instalados en un baño permite detectar la realización de la AVD "tomar una ducha".

Previo al inicio de una corrida de simulación se debe activar el conjunto de sensores que caracterizan el escenario a evaluar. Se define la fecha de inicio y la cantidad de días a simular, y se elige entre una simulación con animación para visualización del escenario o validación del modelo- o una simulación sin animación -para obtención rápida de resultados-. Se configura la probabilidad de ocurrencia de un siniestro con la correspondiente distribución de esa probabilidad entre las diferentes habitaciones de la residencia.

\section{Results and discussion}

The resident profile of the simulated habitat corresponds to an older adult who lives only in his or her habitual residence, somebody who has some type of chronic illness, but is not limited in his or her movements inside or outside the property. In order to generate the sequence of activities, the data were obtained from the filling of a daily activities sheet performed by an 81 year old woman living alone in her private home. Some missing data, by default or forgotten, were completed using the "Random Data" function of the "Calc" Menu belong to Minitab software. Data were entered into a MS-Excel spreadsheet and then they were processed through the Ball software (Evans \& Olson, 1998). It allowed obtaining the probability distribution functions (with their corresponding parameters) of the start time and duration of basic and instrumental activities that best fit the data collected. Figure 2 describes the best fit determined by the Crystal Ball software to the data collected for the "Duration" property of the "Breakfast" activity. Taking into account other activities recorded on the form, the following probability distributions were obtained - the information in parentheses indicates the value of the Anderson-Darling test): sleep: start time: Weibull (0.5227); Breakfast: start time, beta (0.1635); Duration, negative binomial; Lunch: start time, logistics (0.3434); Duration, negative binomial; Snack: start time, normal (0.2004), duration, binomial; Dinner: start time, normal logarithmic (0.1940), duration, Poisson.

Wireless sensor networks were tested in residences of families of the project authors. Sensor performance, installation process, power consumption and communication using the ZigBee protocol (IEEE 802.15.4) were evaluated. Figure 3 shows how the mixed use of temperature, humidity and luminosity sensors installed in a bath allow the detection of EA "take a shower".
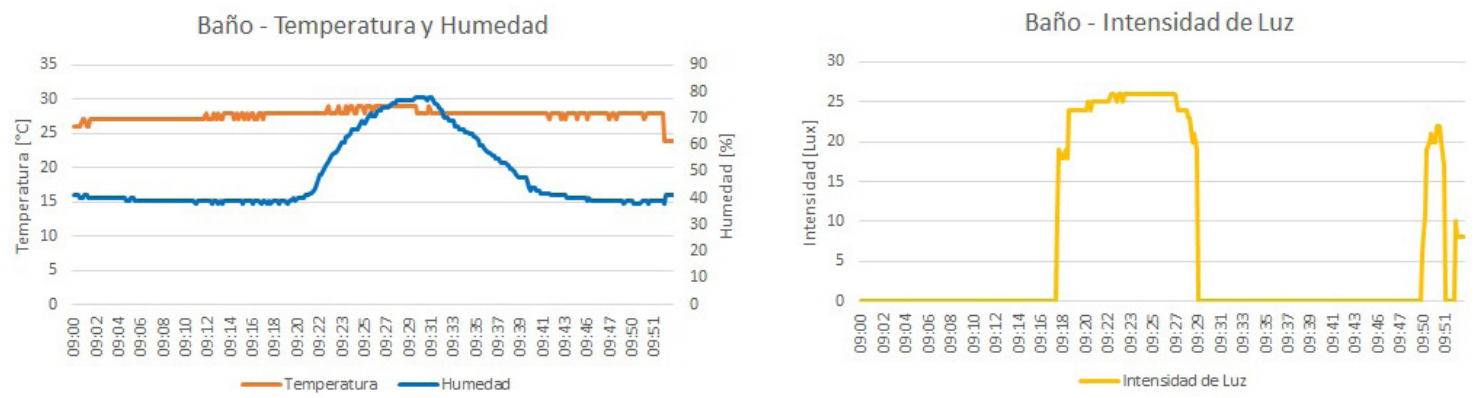

Figure 3. Data collected from sensors in restroom environment / Datos de sensores recolectados en el ambiente "baño" 


\begin{tabular}{|c|c|c|c|}
\hline Actividad & Hora Inicio & Hora Fin & Duracion \\
\hline Dormir & $00: 00 \mathrm{hs}$ & 08:51hs & $531 \mathrm{~min}$. \\
\hline Baño & $08: 51 \mathrm{hs}$ & $08: 56 \mathrm{hs}$ & $5 \mathrm{~min}$. \\
\hline Dormir & $08: 56 \mathrm{hs}$ & 09:08hs & $12 \mathrm{~min}$. \\
\hline Mate & 09:08hs & 09:15hs & $7 \mathrm{~min}$. \\
\hline Tv & $09: 15 \mathrm{hs}$ & 09:18hs & $3 \mathrm{~min}$. \\
\hline Desayunar & 09:18hs & 09:59hs & $41 \mathrm{~min}$. \\
\hline Mate & 09:59hs & 10:03hs & $4 \mathrm{~min}$. \\
\hline Tv & 10:03hs & 10:06hs & $3 \mathrm{~min}$. \\
\hline Mate & 10:06hs & 10:08hs & $2 \mathrm{~min}$. \\
\hline Tv & 10:08hs & 10:32hs & $24 \mathrm{~min}$. \\
\hline Computadora & 10:32hs & 10:43hs & $11 \mathrm{~min}$. \\
\hline Mate & 10:43hs & 10:44hs & $1 \mathrm{~min}$. \\
\hline Computadora & 10:44hs & 11:03hs & $19 \mathrm{~min}$. \\
\hline Tv & 11:03hs & 11:08hs & $5 \mathrm{~min}$. \\
\hline Mate & 11:08hs & 11:10hs & $2 \mathrm{~min}$. \\
\hline Tv & 11:10hs & 11:35hs & $25 \mathrm{~min}$. \\
\hline Computadora & 11:35hs & 12:05hs & $30 \mathrm{~min}$. \\
\hline Tv & 12:05hs & 12:35hs & $30 \mathrm{~min}$. \\
\hline Computadora & 12:35hs & 12:40hs & $5 \mathrm{~min}$. \\
\hline Almorzar & 12:40hs & 13:10hs & $30 \mathrm{~min}$. \\
\hline Tv & 13:10hs & 13:12hs & $2 \mathrm{~min}$. \\
\hline Baño & 13:12hs & 13:17hs & $5 \mathrm{~min}$. \\
\hline Tv & 13:17hs & 13:43hs & $26 \mathrm{~min}$. \\
\hline Almorzar & 13:43hs & 14:00hs & $17 \mathrm{~min}$. \\
\hline Baño & $14: 00 \mathrm{hs}$ & 14:03hs & $3 \mathrm{~min}$. \\
\hline
\end{tabular}

Figure 4. Activities list / Lista de actividades

Prior to the starting of a simulation run, it must be activated the set of sensors that characterizes the scenario to be evaluated. The start date and the number of days for simulation are defined, and a simulation with animation is chosen - in pro of scenario visualization or model validation - or a simulation without animation - in order to obtain faster results. The probability of sinister occurrence with the respect distribution of that probability between the different rooms of the residence is configured.

The system creates an activities sequence for each simulated day. Figure 4 shows the start time, the end time and the duration of the activities to be performed by the resident between 0:00 and 14:03 hours for a simulated day. The activities have associated a priority value in order to solve situations of "tie" in occurrence time. As mentioned above, wheter the occurrence time of one or more activities overlaps with another activity in process, the algorithm places the first ones in a queue and proceeds to execute them according to a FIFO scheme. Some EAs (going to the bathroom, receiving a phone call, taking mate) have a break property for the rest
El sistema genera una secuencia de actividades para cada día simulado. La Figura 4 muestra el horario de inicio, el horario de finalización y la duración de las actividades a realizar por el residente entre las 0:00 y las 14:03 horas para un día simulado. Las actividades tienen asociado un valor de prioridad para resolver situaciones de "empate" en tiempo de ocurrencia. Como se indicó, si el tiempo de ocurrencia de una o más actividades se solapa con otra actividad en proceso, el algoritmo coloca a las primeras en una cola de espera y procede a ejecutarlas según un esquema FIFO. Algunas AVD (ir al baño, recibir una comunicación telefónica, tomar mate) tienen una propiedad de interrupción del resto de las demás actividades. Cuando el algoritmo detecta una interrupción, procede a almacenar el tiempo restante de la actividad interrumpida y reacomoda la lista para que esa actividad sea reasumida al finalizar la interrupción. Durante la corrida, la información recolectada por los sensores se visualiza en un log de sensores y se almacena en una base de datos. La Figura 5 muestra la pantalla principal del modelo durante una corrida con animación. El log de sensores indica la transición del residente simulado desde el baño hacia el living comedor a las 7:36 horas del día simulado 1 de enero de 2016.

La Figura 6 muestra un reporte de métricas donde se indica el día y la hora del registro, el ícono del sensor que está registrando la información, el ambiente de registro, el valor informado por el sensor y el modelo de sensor elegido para la corrida. Se almacenaron en la base de datos 1.055.235 registros durante una corrida de simulación correspondiente a 90 días.

El sistema incluye un conjunto de aplicaciones gráficas que permite visualizar información puntual e información resumida referida a los AVD del residente monitoreado. Así, la FiguRA 7 muestra el porcentaje de ocupación diaria de los distintos

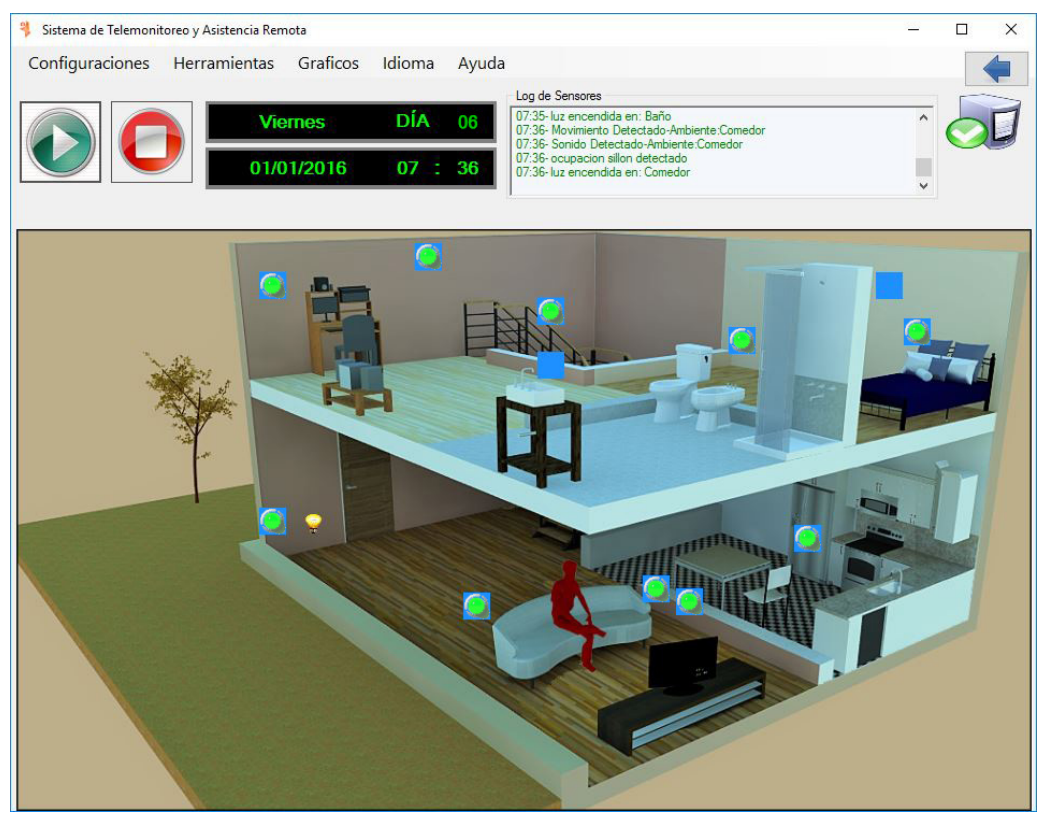

Figure 5. Main view of simulation model / Vista principal del modelo de simulación 


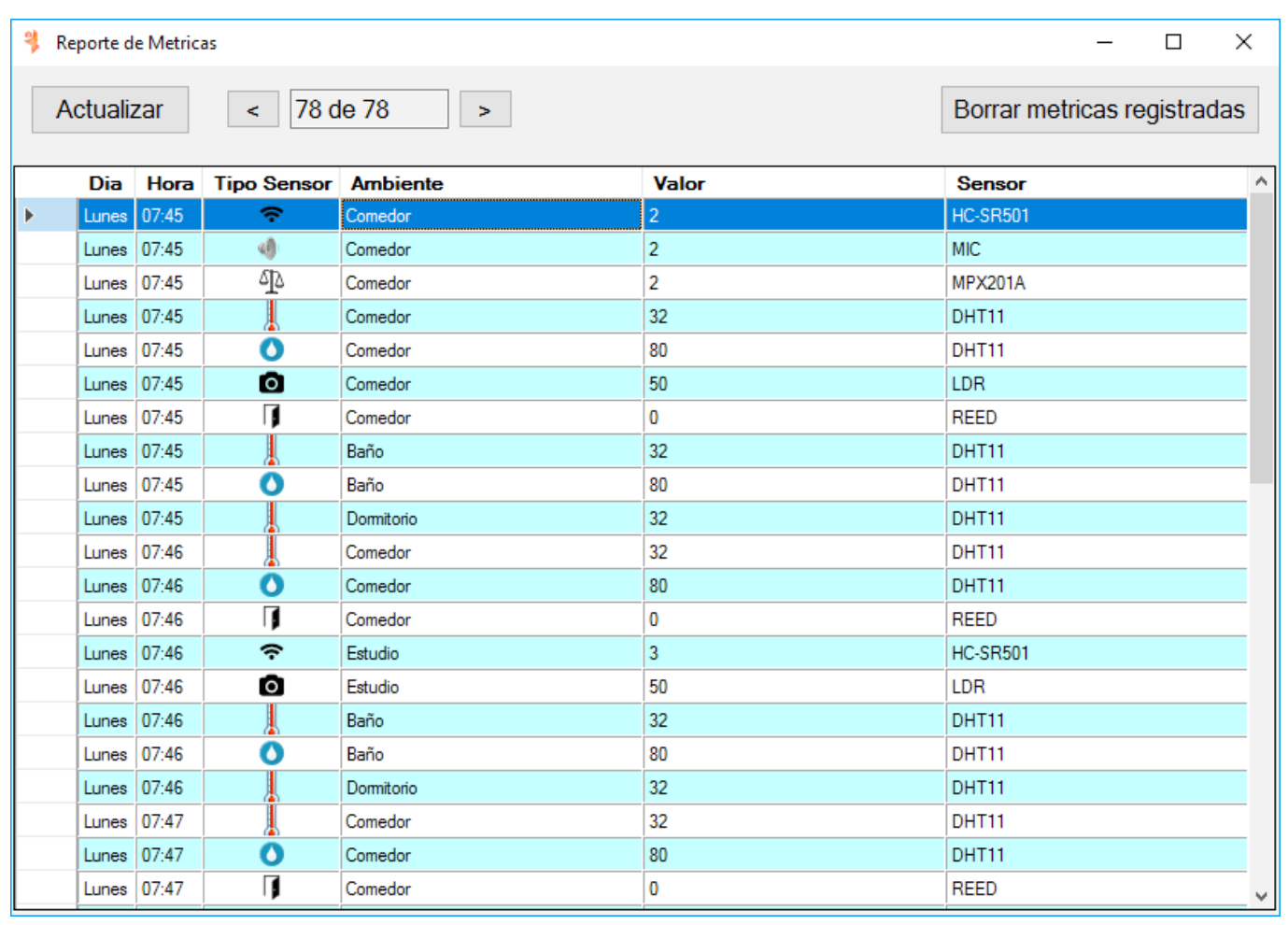

Figure 6. Metrics report / Reporte de métricas

ambientes (incluyendo salida al exterior) para un período simulado de quince días. Como ejemplo, en el día 8 se observa una menor ocupación del dormitorio y una mayor ocupación del comedor. Si esta tendencia se hubiera prolongado durante varios días, podría indicar un posible deterioro en la condición física o cognitiva que justificaría la intervención de un profesional de la salud asociado. Solo se muestran quince días por una cuestión de claridad de visualización de la gráfica.

\section{Conclusiones}

Una de las alternativas más prometedoras para facilitar el envejecimiento en el lugar habitual de residencia de los adultos mayores radica en los hogares inteligentes: sistemas de inteligencia ambiental desplegados en las residencias que

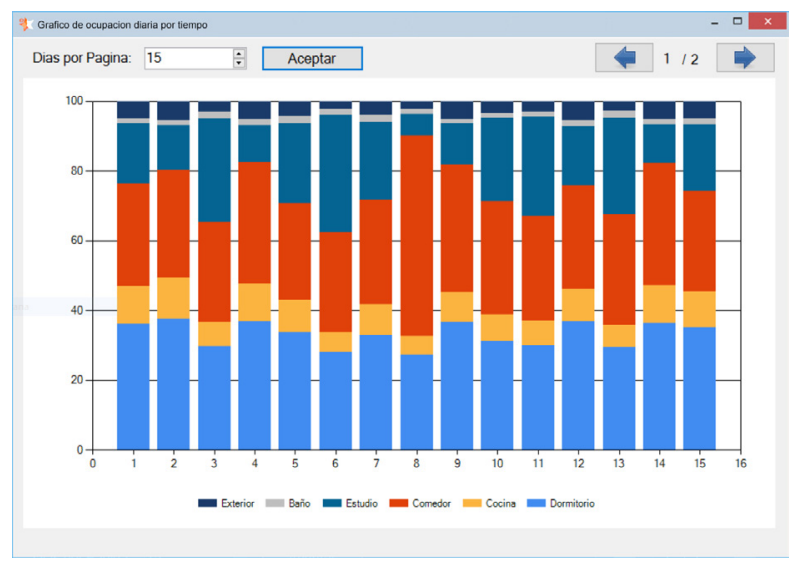

Figure 7. Environment's occupation / Ocupación de ambientes of other activities. Once the algorithm detects an interrupt, it proceeds to store the remaining time of the interrupted activity and resets the list so that activity is taken at the end of the interruption. Throughout the run, the information collected by the sensors is displayed in a sensor log and stored in a database. FIGURE 5 shows the main screen of the model along an animated run. The sensor log indicates the transition of the simulated resident from the bathroom to the living room at 7:36 p.m. on the simulated day January 1st, 2016.

Figure 6 shows a metric report that describes the date and registration time, the sensor icon that is recording the information, the recording environment, the value reported by the sensor and the sensor model chosen for the simulation run. 1,055,235 records were stored in a database with 90-day simulation run.

The system includes a set of graphical applications that allow the visualization of timely information and summary information related to the EA of the monitored resident. Thus, Figure 7 shows the percentage of daily occupancy in several environments (including outbound) for a simulated period of fifteen days. As an example, on day 8 there is a lower occupancy of the bedroom and a greater occupation of the dining room. If this trend has extended for several days, it may indicate a possible deterioration in the physi- 
cal or cognitive condition that requires an associated health professional intervention. Only fifteen days are shown to obtain a display understanding of the graph.

\section{Conclusions}

One of the most promising alternatives to facilitate aging in elderly residence takes place in Smart Homes: environmental intelligence systems deployed in residences that modify habitat with the aim of generating residents' information and sharing with them, their relatives and professionals who provide health services. However, monitoring and remote assistance of older adults with some form of physical or cognitive impairment is a highly complex technological problem. Its implementation is expensive and there are clinical and ethical considerations that must be taken into account.

In order to reduce the constraints and difficulties about the implementation and evaluation of a real environmental intelligence system, it is recommended to use simulation models which generate synthetic sensor data.

In the current research, it was described a simulation model which allowed the obtainment of the mentioned synthetic data sets of sensors. These sensors were used for the development and training of methods and recognition of activities algorithms with the aim of identifying changes in EA that suggest physical and/or cognitive impairments. Hence, it is created an early warning system which improves the elderly life quality and reduces the amount and duration of the older adults in health care centers. $\mathbf{S}$ T transforman el hábitat con el objetivo de generar información del residente y compartirla con éste, con sus familiares y con los profesionales que le brindan servicios de salud. Sin embargo, el monitoreo y la asistencia remota de adultos mayores con algún tipo de discapacidad física o cognitiva es un problema tecnológico de elevada complejidad. Su implementación es costosa y existen consideraciones clínicas y éticas que deben ser tenidas en cuenta.

Para reducir las restricciones y dificultades relacionadas con la implementación y evaluación de un sistema real de inteligencia ambiental, se recomienda la utilización de modelos de simulación que permitan generar datos sintéticos de sensores.

En el presente trabajo, se describe un modelo de simulación que permitió la obtención de los citados conjuntos de datos sintéticos de sensores. Los mismos serán utilizados para el desarrollo y entrenamiento de métodos y algoritmos de reconocimiento de actividades con el objetivo de identificar automáticamente cambios en las AVD que sugieran deterioros físicos y/o cognitivos. De esta manera, se obtendrá un sistema de alerta temprana que mejorará la calidad de vida de los adultos mayores y reducirá la cantidad y duración de ingresos de los mismos en centros de salud asistencial. $\$ S T$ 


\section{References / Referencias}

Acampora, G., Cook, D.J., Rashidi, P., \& Vasilakos, A.V. (2013). A survey on ambient intelligence in healthcare. Proceedings of the IEEE, 101 (12), 2470-2488.

Brownsell, S., Blackburn, S., \& Hawley, M.S. (2008). An evaluation of second and third generation telecare services in older people's housing. J. Telemed Telecare, 14 (1), 8-12.

Cardinaux, F., Brownsell, S., Bradley, D. \& Hawley, M.S. (2013). A home daily activity simulation model for the evaluation of lifestyle monitoring systems. Computers in Biology and Medicine, 43, 1428-1436.

CASAS, Center for Advanced Studies in Adaptive Systems. Retrieved from http://casas.wsu.edu/research-projects

European Commission. (2014). The 2015 Ageing Report. European Economy, (8), 11.

Evans, J.R. \& Olson, D.L. (1998). Introduction to simulation and risk analysis. New Jersey, NJ: Prentice Hall.

Horgas, A., Wilms, H., \& Baltes, M. (1998). Daily life in very old age: Everyday activities as expression of successful aging. The Gerontologist, 38(5), 556-567.

Katz, S., Ford, A.B., Moskowitz, R.W., Jackson, B.A., \& Jaffe, M.W. (1963). Studies of illness in the aged: The index of ADL, a standardized measure of biological and psychosocial function. JAMA, 185, 914-919.

Law, A.M. \& Kelton, W.D. (2000). Simulation modeling and analysis [3th ed.]. Singapore: McGraw-Hill

Massachusetts Institute of Technology [MIT]. (2015). Media Lab Project April 2015. Cambridge, MA: MIT. Available at: http:// www.media.mit.edu/files/projects.pdf

Mobile and Pervasive Computing Research, University of Florida. Retrieved from http://www.icta.ufl.edu/gt.htm

Paré, G., Jaana, M., \& Sicotte, C. (2007). Systematic review of home telemonitoring for chronic diseases: The evidence base. Journal of the American Medical Informatics Association, 14(3), 269 -275.

Phillips Enterprise Telehealth. Retrieved from http://www.usa.philips.com/healthcare/solutions/enterprise-telehealth

Samsung SmartThings. Retrieved from https://www.smartthings.com/uk/

Schnotz, W. \& Lowe, R.K. (2008). A unified view of learning from animated and static graphics. In: Lowe, R.K., Schnotz, W. (Eds.), Learning with animation: Research implications for design (pp. 304-356). New York, NY: Cambridge University Press

Synnott, J., Nugent, C., \& Jeffers, P. (2015). Simulation of smart home activity datasets. Sensors, 15, 14162-14179.

Torrado, S. (2004). Argentina: escenarios demográficos hacia 2025 [Informe preparado para el Programa de Estudios Prospectivos de la Secretaría para la Ciencia, la Tecnología y la Innovación Productiva (SECTIP)]. Buenos Aires, Argentina: UBA. Available at: http://www.econ.uba.ar/www/departamentos/economia/nuevo/depto/materias depto/cursos/557 garciadefanelli/Programa\%202009/Torrado\%20Escenarios.pdf

Van Kasteren, T. Datasets for activity recognition. Retrieved from: https://sites.google.com/ site/tim0306/datasets

Werner, C. (2011, Nov.). The older population: 2010 [2010 Census Briefs]. Washington, DC: United States Census Bureau. Available at: https://www.census.gov/prod/cen2010/briefs/c2010br-09.pdf 


\section{CURRICULUM VITAE}

Darío Weitz Chemical Engineer, Master in International Relationships. Associated professor at the Facultad Regional Rosario, Universidad Tecnológica Nacional, Rosario, Argentina, in "Control theory" and "Simulation". Project Director in "Sensors and systems for environments that improve monitoring and remote assistance to older people" - Code: PID UTN 3784 / Ingeniero Químico con Maestría en Relaciones Internacionales; profesor asociado Teoría de Control, Facultad Regional Rosario, Universidad Tecnológica Nacional, Argentina; profesor titular Simulación, Facultad Regional Rosario, Universidad Tecnológica Nacional, Rosario, Argentina. Director del Proyecto de R\&D "Sensores y sistemas para ambientes que faciliten el monitoreo y la asistencia remota de adultos mayores" - Código: PID UTN 3784.

Denis María Last year student of Systems and Informatics Engineering at Facultad Regional Rosario, Universidad Tecnológica Nacional, Rosario, Argentina / Alumno del último año de la carrera de Ingeniería en Sistemas de Información, Facultad Regional Rosario, Universidad Tecnológica Nacional, Rosario, Argentina.

Franco Lianza Last year student of Systems and Informatics Engineering at Facultad Regional Rosario, Universidad Tecnológica Nacional, Rosario, Argentina / Alumno del último año de la carrera de Ingeniería en Sistemas de Información, Facultad Regional Rosario, Universidad Tecnológica Nacional, Rosario, Argentina.

Nicole Schmidt Last year student of Systems and Informatics Engineering at Facultad Regional Rosario, Universidad Tecnológica Nacional, Rosario, Argentina / Alumno del último año de la carrera de Ingeniería en Sistemas de Información, Facultad Regional Rosario, Universidad Tecnológica Nacional, Rosario, Argentina.

Juan Pablo Nant Last year student of Systems and Informatics Engineering at Facultad Regional Rosario, Universidad Tecnológica Nacional, Rosario, Argentina / Alumno del último año de la carrera de Ingeniería en Sistemas de Información, Facultad Regional Rosario, Universidad Tecnológica Nacional, Rosario, Argentinaa. 